\title{
The Role of Leadership in Bahamian Special Economic Zones
}

\author{
Kemie Alexander Jones \\ (D) 0000-0003-1767-5648
}

\begin{abstract}
During Edward St. George's tenure as co-chair of the Grand Bahama Port Authority (GBPA), he was credited with providing a unique blend of leadership traits which resulted in the city of Freeport's growth. While a great deal of research has been conducted on the role of economic variables in special economic zone (SEZ) growth, little analysis has been conducted on the role of leadership. This paper reviews relevant theories on leadership styles and uses a case study research method to develop a leadership profile of Edward St. George as compared to three of his immediate successors in leading the Grand Bahama Port Authority. The results indicate that core tenets of St. George's leadership were authentic and transformational leadership styles, which were less emphasised by his successors. The results of this paper indicate greater consideration should be placed on these humanistic leadership styles in selecting Grand Bahama Port Authority leadership, in order to encourage greater inclusion and special economic zone growth.
\end{abstract}

\section{Introduction}

In 1955, the Government of The Bahamas entered into an agreement with American investor, Wallace Groves and his British partner, Sir Charles Hayward, to create the city of Freeport as a special economic zone (SEZ). The Grand Bahama Port Authority (GBPA) was created as the entity to carry out the development of the SEZ. Under the terms of the agreement, the developer of the 160,000 -acre SEZ would be granted a variety of tax concessions in exchange for developing a harbour, roads, schools and other key infrastructure (Hawksbill Creek, Grand Bahama [Deep Water Harbour and Industrial Area] Act, 1955). Businesses operating within the SEZ would also benefit from certain tax concessions, all in an effort to spur economic growth in The Bahamas (Hawksbill Creek, Grand Bahama [Deep Water Harbour and Industrial Area] Act, 1955).
In 1979 Mr. Edward St. George and Sir Jack Hayward (son of Sir Charles) bought the shares of the GBPA and assumed control of the company. This ushered in a new era in management of the city, with both gentlemen jointly serving as co-chairmen of the GBPA. The success of Freeport in the 1980s, 1990s and early 2000s, was all attributed to the keen business sense of St. George, his "open door" and relaxed style of management and leadership. until his passing in 2004. Since his passing in 2004, however, despite several attempts to find new leadership for the GBPA, the island has not returned to its vibrant and thriving days.

The economic performance of Freeport before and after 2004 tells a stark tale of the significance of sound leadership in city growth. During the period up until St. George's death in 2004, Grand Bahama consistently posted unemployment levels well below the national average. Note the flat

https://doi.org/10.15362/ijbs.v27i0.383 @ K. A. Jones, 2021.

Journal compilation (CInternational Journal of Bahamian Studies, 2021. 
unemployment rate in Grand Bahama in 1998 and 1999 despite declines in national unemployment levels was largely due to the closure and renovation of the Our Lucaya property with more than 1,000 employees. Unemployment levels in Grand Bahama plummeted below the national average in 2000 with reopening of the hotel property
(Figure 1). In the post-2004 era, with the GBPA under new management and leadership, there has been a marked increase in unemployment levels on the island of Grand Bahama, which peaked at over 20 percent in 2011 (Bahamas Department of Statistics, 2018).

\section{Figure 1}

\section{All Bahamas and Grand Bahama Unemployment Rate (1994-2017)}

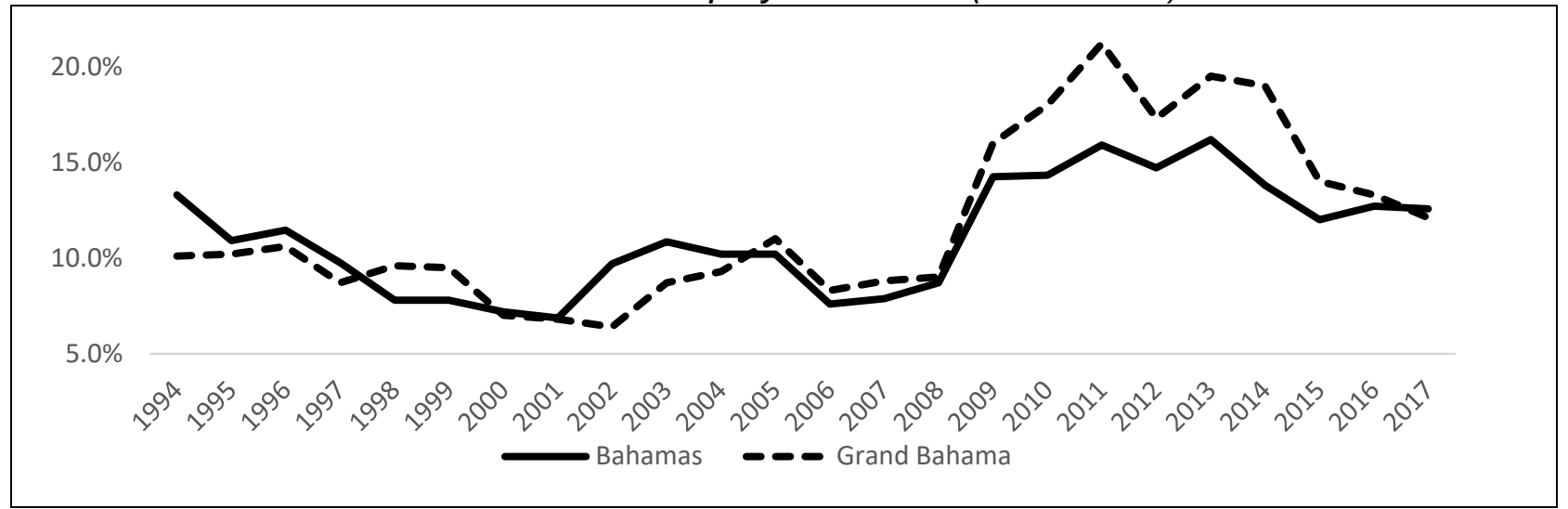

Note: Preliminary results: Labour force survey report. Copyright 2018 Bahamas Department of Statistics.

The historic economic success of the city of Freeport appears to correlate to the tenure of the pioneer, Edward St. George. This raises the question of what aspects of St. George's leadership were so effective in encouraging the growth of the city of Freeport? To identify these aspects, this paper will explore several key questions: (a) What leadership styles and traits did St. George demonstrate during his tenure?; (b) What leadership styles and traits have been demonstrated by the successors to St. George in Freeport?; (c) In what areas are there gaps or deficiencies in leadership which may have contributed to recent poor economic performance in Freeport?

Conceptually, an SEZ is considered a geographic area which is managed by a single entity, offering certain incentives to businesses operating from within the SEZ's boundaries (World Bank, 2008, p. 2). While a great deal of research has been performed in the past regarding the policies and incentives that drive economic growth in these SEZs (Jones, 2021; Jones, 2019; Zeng, 2016; Sing et al., 2008), a significant gap lies in the dearth of research surrounding the leadership component of SEZ success. This paper aims to fill that gap using a case study method to demonstrate the importance of leadership in SEZ management. The findings of this paper provide important guidance for governments on the kinds of skills that should be considered when selecting the right leader to establish or rejuvenate SEZs in their country. In the case of The Bahamas, this paper finds that a balanced leadership style that takes into consideration the type of stakeholder (see Table 1), while focussing on local residents is important. These leadership styles include: situational leadership, authentic leadership, transformational leadership and leader-membership exchange. 
Table 1

GBPA Stakeholder Needs Analysis

\begin{tabular}{|c|c|}
\hline Stakeholder & Need \\
\hline Government & $\begin{array}{l}\text { Largely concerned with consumer protection matters and ensuring economic growth of } \\
\text { Freeport. }\end{array}$ \\
\hline Shareholders & $\begin{array}{l}\text { Largely concerned with profitability of investment in Freeport. Also has regulatory and } \\
\text { management obligations. }\end{array}$ \\
\hline Foreign Investors & $\begin{array}{l}\text { Largely concerned with profitability of investment in Freeport and competitiveness of } \\
\text { destination as compared other destinations. }\end{array}$ \\
\hline Local Businesses & $\begin{array}{l}\text { Largely concerned with the state of the local economy, its competitiveness and the ability of } \\
\text { locals to participate and earn a living. }\end{array}$ \\
\hline Residents & $\begin{array}{l}\text { Largely concerned with overall quality of life in Freeport, both economic and social } \\
\text { considerations (e.g., jobs, schools, etc.). }\end{array}$ \\
\hline
\end{tabular}

\section{Literature Review}

Literature on the rationale and benefits of creating a SEZ, from a theoretical standpoint, is quite extensive. According to Zeng (2016), countries typically create SEZs to achieve one or a combination of the following objectives:

1. Increase foreign direct investment (FDI).

2. To decrease unemployment.

3. As part of an overall economic plan. and/or

4. To provide a zone to test policies before wider implementation (p. 3).

The structure of SEZs has evolved over the years to achieve these goals and include a variety of operational models. While the target and design of SEZs may have expanded and grown over the years, the basic features of the SEZ model have remained the same. According to the research of Zeng (2016), SEZs features remain: (a) creating a defined zone; (b) creating a single, defined administration; (c) providing physical advantages for investors; and (d) creating a separate customs process/zone.
In more recent research, Jones (2019) investigated the impact of investment policy reforms on the inflow of FDI into The Bahamas between the 1981-2017 period. Using an ordinary least squares model, FDI receipts in The Bahamas were compared to the Dominican Republic, Ireland and China, other countries that also adopted SEZ driven FDI strategies. While controlling for location, time and the benefit of the late comer's advantage, the model tested for the impact of wage rates, labour force size, inflation, investment policy, labour productivity, level of infrastructure investment and market size on FDI growth. The findings of the study suggest that policy reform, wages, labour productivity and size of the labour pool were significant in determining the level of FDI investment in The Bahamas. The study also indicated that infrastructure investment, a component typically under the direction of the SEZ manager, was also significant in determining the level of FDI investment in The Bahamas. This variable was also determined to be significant in the stylized ordinary least squares model for both China and the Dominican Republic (Jones, 2019). 
In the research of Long (2018) on the success of the sustained growth in the Chinese economy over the past 40 years, it was revealed that the Chinese growth strategy was based on several factors: sustained investment; a reform strategy; and its opening-up strategy. China has long boasted one of the highest levels of investment in the world, largely supported by a high domestic savings rate. The investment priority was mandated by the reform strategy which allowed for economic diversification into new and more productive sectors, along with redirection of labour and supporting resources. In the case of China, to encourage FDI investment, several SEZs were created with specialized foci and a strong management structure to facilitate investment.

According to Long (2018), to encourage FDI flows into China, a strong management structure was implemented within SEZs to simplify the investment process, which included the steps below:

1. adopt a risk-based approach to investment approval (Long, 2018, p. 24);

2. document simplification process (Long, 2018, p. 26)

3. introduce one-stop-shop application processes and single windows for service delivery (Long, 2018, p. 28)

4. define time limits for approval of applications (Long, 2018, p. 29)

5. assign dedicated persons on a case-bycase basis to improve the investment experience (Long, 2018, p. 32)

In the Chinese model, a strong management structure has proven important to the ease of FDI flow into the country, and in particular to encourage flows into Chinese SEZs.

Similar to the work of Long (2018), the work of Zeng (2015) provides a review of the success factors for SEZs in China, but also includes a review of the success factors of SEZs in Africa, many created with Chinese investment. China has several successful examples of SEZs, which are estimated to have contributed up to $46 \%$ of FDI flows into China in recent years (Zeng, 2015, p. 4).

While the Chinese zones implemented investment incentives, received support from government, allowed for innovation and possessed locational advantages, there are two key factors that allowed for SEZ success in Africa.

First, SEZs were created with clear objectives that were time-bound, tracked, measured and placed significant pressure and responsibility on the zone manager to achieve these targets (Zeng, 2015, p. 6). And, second, along with greater responsibility placed on the zone manager, the SEZ was given significant legislative autonomy to implement policies and measures to achieve the specified targets (Zeng, 2015, p. 5).

For zones in Africa, it was recognized that there were several factors which resulted in poor SEZ performance. Factors such as poor and outdated legal and regulatory frameworks (Zeng, 2015, p. 9), lack of proper zone management and instead a reliance on zone developers who have limited management experience (Zeng, 2015, p. 10); and a lack of government commitment and support which becomes an increasing challenge when there is a new government (Zeng, 2015, p. 10).

\section{Theoretical Background}

\section{Leadership Defined}

While there is no standardized definition of leadership, there is general consensus on the key components of leadership as presented by contemporary theories. Rost (1991) and Lussier and Achua (2007) define leadership 
as a relationship between a leader and follower to effect change for a mutual purpose. Similarly, Kouzes and Posner (1995) and Rowe (2007) simply refer to leadership as the ability to mobilize others to achieve a common goal. Conceptually, leadership can be categorized into two categories: 1) the leadership theory which categorizes the traits, behaviour and skills of the leader to influence the group; and 2) leadership style which categorizes the manner in which the leader motivates the follower(s).

\section{Leadership Theories}

\section{Trait-Based Theory}

One of the earliest leadership theory models, the trait-based theory, is a leader-centred approach. This theory focusses on the leadership traits exhibited by the leader, such traits being inherent in the leader naturally since birth with only select persons possessing these traits. Some of the earliest work surrounding trait-based leadership theories included 124 studies conducted by R. M. Stogdill from 1904 to 1947. In his pioneering study, he found the common traits among leaders to include intelligence, alertness, insight, responsibility, initiative, persistence, self-confidence, and sociability (Stogdill, 1948).

Similar to the work of Stogdill was the 1959 paper by R. D. Mann which evaluated leadership based on over 500 measures of personality as demonstrated by leaders in small group studies with a sample size of 1,400 observations. With little exception, the traits tested and identified were characterized into seven dimensions: intelligence, masculinity, adjustment, dominance, extraversion, conservatism and interpersonal sensitivity (Mann, 1959). The prevalence of work by researchers such as Stogdill and Mann encouraged the dominance of concepts such as the great man theory-the theory itself exemplifying the inherent traits of leaders such as Abraham Lincoln, Napoleon Bonaparte and other great figures in history.

\section{Skills-Based Theory}

Whereas the trait-based theory focusses on characteristics that are innate and unchanging, the skills-based theory focusses on skills that can be learned and developed over time. One of the most influential bodies of work relating to this theory is the 1955 work of R. L. Katz. In his leader-centred skills-based theory, he places the skills of a leader into three categories: technical skills, human skills and conceptual skills. Conceptually, technical skill is defined as the knowledge and capacity required to work in a field, whereas human skill is the ability and capacity to work with people. Balancing both technical and human skill is the conceptual skill which involves working with ideas (Katz, 1955).

For the skills-based theory of leadership to be successful, particularly in organizations, more contemporary researchers such as Bass (1990) contend that varying amounts of the three leadership components are needed at different stages of an individual's career. During early years of organizational leadership, when one is closer to the data and to the project team, technical skill is more important. This is in contrast to later and more senior years of leadership where guidance of junior leaders is needed, and conceptual skills are more important as the leader and the team itself mature (Bass, 1990).

\section{Situational Leadership Theory}

Being sensitive to the level of development of both leader and follower, the situational leadership model later emerged from the duo of Hersey and Blanchard in the late 1960s. 
This theory addresses the deficiencies of the prior theories and is built on the concept that leaders must adopt a style which adjusts for the needs of the persons being led to be most effective (Hersey \& Blanchard, 1969). This leadership model eventually evolved into a model which requires the leader to be attuned to the state of development of the follower(s) and to discern when to take over or when to guide, when to delegate or when to provide greater support (Hersey \& Blanchard, 1993). In terms of leadership theory, this revolutionary approach is one of the first theories of leadership that looks beyond the leader and their capabilities to examine the follower(s), albeit from the perspective of the leader.

\section{Leader-Member Exchange Theory}

In contrast to earlier leadership theories which focussed exclusively on the leader, the leader-member exchange theory is the first to commodify the role of leadership and focus on the subsequent interactions between leaders and followers. This theory also diverges in that it focusses on the one-on-one interactions between a leader and a single team member, as opposed to the leader and the entire team. Pioneering this theory was the 1975 work by Graen and Cashman (1975), which studied the interactions between leaders and followers and the motivation behind the exchanges.

Subsequent to this seminal work, studies and analysis further expanded the leader-member exchange, with leadership being defined as a barter, where members follow the leader for benefits being granted. These benefits may be tangible (e.g., payment) or intangible (e.g., being considered a trusted colleague and having influence in the workplace; Graen, 1976; Graen \& Uhl-Bien, 1995).

\section{Transformational Leadership Theory}

The transformational leadership model is based on the work of American political scientist James MacGregor Burns in the 1970s. In his model, Burns (1978) describes leadership as a process of engagement between leader and follower where both parties feel motivated and achieve a raised sense of morality at the end of the exchange (Burns, 1978). This leadership trait is thought to be present in many of the great inspirational leaders throughout history, such as Ghandi, who leave others around them feeling changed and inspired at the end of the interaction (Northouse, 2016). This model is a stark contrast to the transactional leadership style such as the leader-member exchange, which describes leadership as a commodity for barter. In the transformational leadership model, the only items exchanged are a sense of empowerment, fulfilment and an emotional connection between both parties.

\section{Authentic Leadership Theory}

The final and most recent leadership theory is the concept of authentic leadership. While there is difficulty among scholars concerning how to define the concept of authentic leadership, the best definition comes from Walumbwa et al. (2008), who describe the concept as leadership based on strong moral, ethical and psychological behaviour. The features included in this theory are those typically those depicted by a priest or other religious figures who lead by providing firm moral guidance to others.

\section{Leadership Styles}

In tandem with the various theories of leadership, a leader is distinguished by the manner in which he/she implements his/her brand of leadership to motivate employees. This concept is referred to as leadership style and is characterized in several categories. 


\section{Autocratic Leadership}

The autocratic or authoritarian style of leadership is one of the most efficient styles of leadership characterized by a leader with complete control over staff and team members. Under this style of leadership, all authority and decision-making power rests with the team leader who assumes responsibility for the direction of the team and its activities. In this model, decisions are made quickly as all authority rests with a single individual and is usually best suited for crisis management scenarios or scenarios where team members are low skilled. Unfortunately, this management style requires a great deal of dependence upon the leader and can cripple progress, should the leader be unavailable for any period of time (Khan et al., 2015).

\section{Bureaucratic Leadership}

This style of leadership is characterized by a rigid rules-based style which guides the actions of the leader as well as the staff and team members. This style of leadership is best suited for high-risk environments where safety is a concern and environments where team members perform routine tasks on a daily basis. This style may also be appropriate for teams with very high levels of education or training, and diversity of opinion is needed to produce the best product. Most importantly, this style of leadership is commonly appropriate for scenarios where large sums of money are involved, and as such, appropriate controls are needed to prevent theft or abuse (Amanchukwu et al., 2015).

\section{Charismatic Leadership}

Similar to the transformational leadership theory, this style of leadership is characterized by an approach designed to inspire staff and team members to willingly comply. While this method results in high levels of commitment and productivity from staff and team members, this high productivity is due solely to the inspiration provided by the leader. Should the leader depart the environment, the structure may collapse (Amanchukwu et al., 2015).

\section{Democratic Leadership}

The democratic style encourages collaboration, creativity and free speech, with the final decision-making power residing with the leader. This style of leadership is best suited for environments that require high levels of creativity to produce the final product. Due to the need for consensus among the team, this style of leadership is also one of the least efficient leadership styles. The loss in efficiency, however, is compensated for by having a more relaxed work environment and a loss of tension in the work environment due to the consensus nature of this approach (Val \& Kemp, 2012).

\section{Laissez-Faire Leadership}

As the name implies, this style of leadership comes from the French term laissez faire which implies a stance of not restricting the freedoms of another. In this style, the leader adopts a "hands off" approach to leadership, allowing staff and team members the right of self-management with the team leader being relegated to monitoring progress only. While this style of leadership allows for a great deal of creativity and innovation, it relies on staff being disciplined to manage themselves and manage their times (Val \& Kemp, 2012). Such a style of leadership is best suited for highly skilled and highly motivated groups or persons who do not need direct supervision or guidance from the team leader.

\section{Transactional Leadership}

Similar to the transactional leadership theory, the transactional style of leadership is characterized by exchange between the 
leader and individual staff member. The exchange between both parties usually involves a tangible reward or punishment being granted in exchange for compliance or lack of compliance in the workplace. A major drawback of this style of leadership is the lack of loyalty generated between the leader/staff member and little real change in behaviour. As followers are not engaging in the behaviour of their own nature and solely to receive a reward, should the reward cease, the desired behaviour would also cease (see, for example, Nanjundeswaraswamy \& Swamy, 2014; Bass \& Avolio, 1994).

\section{Methodology}

This paper utilizes a qualitative research method, largely relying on historic archives, news clippings, journal articles and other source material which document demonstrations of leadership across the various timespans of the multiple GBPA chairpersons. A theoretical framework was developed which outlines the role of leadership in the success of SEZs, based on theories of leadership styles and leadership theories. Based on these leadership approaches, a case study was developed to assess the performance of various chairmen of the GBPA to identify strengths and potential weaknesses, which resulted in lower economic performance, higher unemployment and a general lack of satisfaction in the direction of Freeport.

\section{Case Study of GBPA Leadership Experience}

The Grand Bahama Port Authority was formed as a result of the Hawksbill Creek Agreement to fulfil the mandate of development, administration, management and provision of the required services in the city of Freeport. These requirements included the development of certain infrastructure such as the dredging of a deep-water harbour, hospital and utilities (Hawksbill Creek, Grand Bahama [Deep Water Harbour and Industrial Area] Act, 1955, p. 6). The structure of the GBPA is that of a regulator with subsidiary companies that engage in commercial activities within Freeport such as the Grand Bahama Utility Company, a necessary commercial entity which delivers utility services as part of the GBPA mandate. The GBPA is headed by a chair and board of directors who provide overall general guidance and policy direction, which are then executed by the president and the executive management in their day-to-day operational role. As a co-chair of the GBPA, St. George was a lead party in the GBPA's relationship management with a diverse group of individuals.

\section{Edward St. George (1979-2004)}

In review of the history and St. George's rise to leadership in Freeport, there are several features of his life and history that suggest his style of leadership. Chief among these activities were: his extensive international business experience; his vested interest in Freeport as a shareholder of the GBPA; and his philanthropic spirit.

The demonstrable characteristics of the late Edward St. George's leadership style overlap several traditional categories: situational leadership, authentic leadership, leadermembership exchange and transformational leadership.

\section{Situational Leadership}

In his legacy, St. George demonstrated a firm sense of situational leadership in guiding the general business community, working with government, communicating with fellow shareholders, enticing investors and comforting residents. Understanding the delicate balance of these various stakeholder groups, one of the core leadership models 
adopted by St. George was the flexible situational leadership style in managing the ever-changing needs of these stakeholders. So fundamental was situational leadership to St. George's style of leadership that immediately upon coming to leadership of the GBPA in 1979, one of St. George's first activities was to immediately call a meeting with the Prime Minister of The Bahamas. This meeting was critical as it demonstrated a keen understanding of the need for collaboration between central government and the GBPA for the success of Freeport. During this meeting, clear plans for the development of Freeport were presented to get buy-in from central government and allow the plans to be adapted to the satisfaction of all parties. Chief among these commitments included items such as increased Bahamian labour participation in GBPA operations (“The Man” 1981).

Further clarifying the importance of the situational approach adopted by St. George was the strategic nature of the management of the relationship with government. This was emphasized by St. George who stated:

I knew that if we worked hard, it would take two or three years to turn the whole place around. I accepted that Government would still view us with suspicion until they were convinced that what we were trying to do was something for the benefit of all the Bahamas. Once we succeeded in convincing them of that, then we got their co-operation, and the place started to boom and we haven't looked back since. ("The Man," 1981)

While the above example highlights the need for situational leadership in collaborating with government, numerous examples can be provided a situational approach to being used to address the needs of other stakeholder groups. It is for this reason that St. George earned the reputation of being an "aggressive, resourceful, self-made entrepreneur" ("The Man," 1981).

\section{Authentic Leadership}

Similar to the demonstration of situational leadership, authentic leadership was ingrained in to the nature of St. George and to his tenure as co-chair of the GBPA. In his demonstration of authentic leadership, St. George went beyond the international standard of encouraging the GBPA to demonstrate corporate social responsibility to the residents and businesses on the island of Grand Bahama. The demonstration of authentic leadership was a personal undertaking on his behalf and was displayed in his everyday life. In the case of Freeport, the authentic leadership style was a key variable in building trust of the GBPA and St. George's commitment from government, residents, local businesses, shareholders and foreign investors.

In recounting the authentic leadership style of St. George, one prominent local businessman described the pair of Mr. and Mrs. St. George as often "doing more for the poor and disadvantaged on Grand Bahama than the politicians" (Percentie, 2005). The same businessman recounts a personal experience of touring a low-income area of Freeport with St. George, who did not hesitate to walk through the crime-ridden area leisurely and calmly. It was at this time, and on many more occasions, where he was seen going into the homes of residents, casually placing money in the hands of the less fortunate tenants, and bringing a smile to the faces of many (Percentie, 2005). Needless to say, this act of kindness established a model of community mindedness for the city of Freeport and by extension, the island of Grand Bahama, based on the leadership of one man. 
In addition to the direct support provided to residents in his walkabouts, St. George also created and strengthened social support networks on the island to broaden his reach. In collaboration with his wife (a former kindergarten teacher and children's nurse), St. George took up the mantle to establish the Grand Bahama Children's Home to fulfil the need of the many neglected children in Grand Bahama. Going further, the St. Georges established other entities such as the Beacon School for disabled children, the Genesis Academy for difficult students and the Pace Centre for pregnant teens (Grand Bahama Port Authority Ltd., 2005). While the establishment alone of these much-needed social agencies was an achievement, these agencies also received regular support from the St. George family to sustain and expand themselves. These acts of compassion, in the absence of local corporate social responsibility legislation or a mandate, gave a strong sense of the compassion, moral fibre and integrity he possessed.

\section{Leader-Membership Exchange}

One of the fundamental beliefs of St. George was that cooperation at all levels, including between ownership and employees was essential for the development of Freeport. He was once quoted as saying, "so long as we go on working as a team, this place is going to be an example to every community in the world" ("The Man," 1981). In line with the leader-membership exchange theory, during the tenure of St. George as co-chair of the GBPA, direct employees of the GBPA were awarded benefits and opportunities to encourage loyalty among staff and further the objectives of the organization.

One important benefit offered to staff and employees at the GBPA was secure tenure and room for advancement in the organization. This was a major shift in employee relations since the founding of the
GBPA. In 1979 upon St. George assuming the reigns of the GPGA, the company was composed of $46 \%$ foreign labour ("The Man," 1981). Under the guidance of the new chair, the entire company's business model was adjusted such that by 1982, the staff comprised less than $10 \%$ foreign labour and less than three per cent foreign employment at the executive level ("The Man," 1981). Anecdotally, reports were made of additional compensation to employees such as subsidized tuition for children of GBPA employees attending private elementary and secondary schools and subsidized electricity rates for GBPA staff.

\section{Transformational Leadership}

The final significant leadership trait demonstrated by St. George was that of transformative leadership delivered largely by education and providing a means for individuals to attain a higher social standing. The focus on education came at a time in the late 1990s when schools across The Bahamas faced challenges of access due to limited premises, limited teaching staff and sometimes significant distances between settlements. The stated focus of the government at the time was "achieving the long term goal, to improve the quality and increase the access of ordinary Bahamians to quality education and skills training" (Greene, 1998). The focus of the GBPA and St. George on education was not only key in transformational leadership and providing a devoted and capable future workforce, but it also solidified the position of the company with government and demonstrated alignment of both GBPA and central government's goals.

In a show of solidarity with government, the GBPA supported the creation of a junior and senior high school in Freeport, named after each co-chair, Edward St. George and Sir Jack Hayward. The estimated budget for each 
school was \$3.5 million with a view of creating first class educational institutions for the island (Greene, 1998). It is clear that St. George was of the understanding that the transformative impact of good education not only provides a strong, competent work force for the GBPA in the future, but the investment also engendered loyalty in future staff of the company. In addition to sound educational facilities, St. George personally committed to and ensured that the quality of education at the school bearing his name was exceptionally competitive and preparatory for future life. To this end, separate awards and prizes were established for students in mathematics, arts and spelling on a competitive basis with its sister school, Jack Hayward (Greene, 1998). Later, both schools were upgraded to include gymnasium facilities and a school band, the first of its kind on the island (see Table 2).

\section{Table 2}

Summary of St. George's Leadership

\begin{tabular}{l|l}
\hline Stakeholder & Leadership Theory \\
\hline Government & Situational Leadership; Authentic Leadership \\
Shareholders & Situational Leadership; Authentic Leadership \\
Foreign Investor & Situational Leadership; Authentic Leadership \\
Local Businesses & Situational Leadership; Authentic Leadership; Transformational Leadership \\
Residents & Authentic Leadership; Transformational Leadership; Leader-Membership Exchange \\
\hline
\end{tabular}

\section{Assessment of GBPA Successor's Leadership}

After the passing of the passing of Edward St. George (and the untimely death of his business partner and co-chair) attempts were made to appoint new leadership to the helm of the GBPA. These new leaders, however, did not have the same impact on the economy as St. George did, for numerous reasons. Below I explore the leadership of three noted persons who immediately replaced St. George, namely Julian Francis, Hannes Babak and Ian Fair.

\section{Julian Francis (2005-2006)}

Following the death of St. George, Julian Francis was named as the new co-chair and chief executive officer of the GBPA in 2005. To his credit, Francis held a Master of Business (Finance) from the prestigious New
York University and came with years of experience with progressive responsibility, gained working at an international bank in France. $\mathrm{He}$ is also credited as being instrumental in the creation of BISX (Bahamas International Securities Exchange). In addition, at the time of his appointment to the GBPA, Francis was ending his tenure as Governor of the Central Bank of The Bahamas. During his tenure as Governor, Francis worked very closely with the nation's Prime Minister (Perry Christie) and other senior level officials to strengthen the regulation of The Bahamas' financial services sector. These tasks included leading drafting the legislation of modern legislation and accompanying the Prime Minister and his delegation on foreign missions (King, 2005). With a first-class education, international experience and a prior close working relationship with central 
government, Francis appeared to be the ideal replacement for St. George.

Using acute business acumen, Francis quickly estimated, similarly to St. George, that a situational leadership style was important to Freeport and described his role as such: "the ultimate responsibility is to work with the various sectors, the business sector, the labour sector, the government and potential investors, to really make Freeport what it can be and what has always been the dream of its founders" (King, 2005). Most notably, the list of parties named by Francis did not include the shareholder group as a key party to be managed, a mistake that ultimately proved detrimental to his tenure at the GBPA as co-chair. Francis explained his quick departure from the GBPA solely as failing "to see eye-to-eye with the company's owners on the future development of Freeport" (Dames, 2006); this underscores previous statements made by Francis in 2005 upon assuming the role of co-chair where he did not place sufficient emphasis on the company owners. This failure is attributed to a need for a structured, policy/rule-based method to develop the city of Freeport and ultimately Grand Bahama.

While the need for stronger shareholder engagement and consensus is important, it does not eliminate the need for other leadership traits in the management of Freeport. While the tenure of Francis was not a very long one, previous statements indicated a strong intent to focus on development and empowerment of staff such as St. George's transformational leadermember exchange leadership style did. $\mathrm{Mr}$. Francis was quoted as stating that a fundamental part of his management style while serving as Governor of the Central Bank was to garner confidence and support of the professionals at the Central Bank and later implied a desire to do the same for the professionals at the GBPA (King, 2005).
However, similar to ignoring the needs of shareholders, at no point did Francis indicate a stated intent to focus on community building in the authentic manner of St. George, a core component of his leadership.

\section{Hannes Babak (2006-2009)}

Following the resignation of Francis as cochair of the GBPA, almost immediately Hannes Babak assumed the role as co-chair. Similar to the characteristics of St. George and the criteria used for the selection of Francis, Mr. Babak possessed many notable characteristics: first of all, he was a resident of Freeport for over 5 years before his appointment, allowing him to generate ties to the city; second, as an Austrian citizen investing in The Bahamas, Babak had similar international experience and an international investor's perspective as St. George; and finally, as an investor in Freeport Mr. Babak had financial ties to the city similar to St. George, ensuring a vested interest in the success of the city.

As an international businessperson, Babak was astute as a situational leader and managing the needs of the international business community, as well as the stakeholder group. A critical fault of the GBPA under the leadership of Babak, however, was to discount the role and significance of government and staff of the GBPA in the management of Freeport. As mentioned prior, after coming to the helm of the GBPA in 1979, St. George heeded the call of government and Bahamians to adopt a policy of reducing foreign labour in the GBPA and promoting Bahamians where possible, particularly to executive positions. After the departure of Francis, however, the GBPA saw changes that were in contrast to this: appointment of Austrian-born Hannes Babak as co-chair; the resignation of executive vice president, Barry Malcolm; redundancy of deputy chair, Willie Moss; and 
the resignation of Bahamian directors Sean McWeeney and Cyprianna McWeeney (Dames, 2006). The removal/resignation of many executive Bahamians in the company, in tandem with the appointment of an expatriate to the helm of the GBPA proved a disincentive to local staff and soured the relationship with government, a matter the new chair never sought to resolve.

While the efforts of Babak to restore the economy of Freeport were admirable, ultimately the relationship with government was not sufficiently mended, and by December 2009 his work permit was not renewed, and he was asked to leave the country. Further clarifying the matter, a US embassy official was cited as stating the reason for refusal to renew the work permit, "was likely made out of anger at Babak's move not to obtain (Prime Minister) Ingraham's blessing moving forward with the Mid-Atlantic deal as well as not-so-discreet desire to increase Chinese involvement in Grand Bahama's development plans through Hutchison-Whampoa (a Chinese company with major business interests in Freeport)" (McCartney, 2011).

\section{lan Fair (2012-2013)}

After a lengthy period from 2010-11, although it still maintained a Board of Directors, the GBPA had no chair until August 2012 when it appointed its final chair, the renowned businessman Ian Fair. Similar to his predecessors, Fair brought with him years of experience in international business and sound experience in corporate governance. At the time of his appointment, Fair boasted a stellar career which included over 40 years of business experience in The Bahamas, chair of the Bahamas First Insurance Group (the largest property and casualty insurer in the country with deep international ties); chair of Butterfield Trust (Bahamas); founding chair of The Bahamas
Financial Services Board; chair of the Bahamas International Securities Exchange; and director of the Governor General's Youth Award. With a stellar record of experience at the board leadership level, Mr. Fair indeed appeared to be ideal for the role of chair of the GBPA.

In comparison to his predecessors, Fair was able to maintain an appropriate balance among the shareholders and the government as chair of the GBPA. Commenting on the performance of Mr. Fair as chair, Sir Jack Hayward was quoted as stating, "Mr. Fair has done a tremendous job in both companies and he leaves us in a stronger position than he found us. Thanks to his corporate governance and business expertise he now departs a group better prepared to take on the challenges that lie ahead" ("Ian Fair Departs GBPA," 2013). With respect to central government, there were no noted challenges or clashes with Fair, likely owing to his years of experience and long-standing relationship with key government officials due to his many board of director posts.

While Fair was very accomplished in his role as chair of the GBPA, the major challenge to a lasting role as chair was a lack of physical presence. To the credit of Edward St. George, Julian Francis and Hannes Babak, during their tenure as chair each was resident in Grand Bahama, allowing for considerable time to be devoted to managing the operations of the GBPA. Fair later realized this fact and stated, "as time has gone on it's become pretty clear along the way that the way it (GBPA) operates requires a lot of hands on by me, and I just don't have the time" ("Ian Fair Departs GBPA," 2013). To truly provide authentic leadership and inspire confidence in the city of Freeport, it was evident from the tenure of St. George that extensive time and devotion was required to interact with local businesses, residents and with government. Given Fair's numerous 
other commitments, including his position as chair in several of these posts, the extensive commitment required by the GBPA proved a challenge. Ultimately, with Fair being unwilling to relocate to Grand Bahama permanently, his tenure came to an end with the statement, "Frankly, I miss my family" ("Ian Fair Departs GBPA," 2013).

\section{Implications for Successful Leadership of the GBPA}

Based on an analysis of the leadership traits and leadership style of St. George and the resulting success, as compared to the limited success of ensuing chairmen, there are several clear lessons to be learned from leadership of the GBPA over the years. While there are certainly many other traits which one may attribute to St. George, the traits of situational leadership, authentic leadership and transformational leadership present a rounded view. With these traits alone, he was able to inspire the local labour force, government partners and foreign parties to invest in Freeport; the traits demonstrated by
St. George were sufficient to encourage investment by international parties, garner support of the government and create a sense of hope within the residents and local business community. The leadership methods adopted by St. George in his role as co-chair of the GBPA were adapted to meet the needs of the stakeholder group members. In summary, the use of the various leadership theories adopted are aligned to the following stakeholder groups (see Table 1):

After the death of St. George, great efforts were made to find a suitable replacement to step into his role as co-chair of the GBPA, thereby providing leadership for the city of Freeport. Three candidates, Julian Francis, Hannes Babak and Ian Fair were described in terms of the traits both leaders possessed and what ultimately caused their failure in the post. While all three individuals possessed reputable backgrounds and experience, each lacked in certain key areas of leadership which limited their effectiveness in the role (Table 3).

\section{Table 3}

Summary of Successors Leadership

\begin{tabular}{lll}
\hline Successor & Leadership theory/style & Issue(s) \\
\hline Julian Francis & $\begin{array}{l}\text { Situational Leadership } \\
\text { (limited) }\end{array}$ & $\begin{array}{l}\text { Less focus on the shareholder group and the need to reflect this } \\
\text { group's interest in the development of Freeport. }\end{array}$ \\
Hannes Babak & $\begin{array}{l}\text { Situational Leadership } \\
\text { (limited) }\end{array}$ & $\begin{array}{l}\text { Discounted the relationship and role of government in the } \\
\text { success of Freeport. Also ignored transformational/leader- } \\
\text { membership exchange leadership to inspire and empower staff. }\end{array}$ \\
lan Fair & Situational Leadership & $\begin{array}{l}\text { Unwilling to relocate to Freeport and thus limited ability to } \\
\text { stimulate authentic leadership and other leadership methods. }\end{array}$ \\
\hline
\end{tabular}

Learning from the case study of leadership styles and traits that resulted in the historic success of the GBPA, as well as based on global examples, several lessons are evident.

In selection of a new chairperson, greater consideration should be given to the benefits of transformational leadership in such that they engender greater buy-in from the community and other stakeholders. This component is essential to the success of any SEZ as this contributes to strengthening of the SEZ labour force and small business community. This should be heavily encouraged on a personal and professional level for persons at the helm of the GBPA. 
Similar to the inspirational impact of transformational leadership, a hallmark of the St. George chairmanship was a focus on authentic leadership. While the leadership of successive chairmen may have continued the support of the GBPA's standing charities and efforts, in his role, St. George gave considerably from his own personal time and pocket.

Encouraging a balanced approach to leadership is paramount, such that, as much as possible, all stakeholders' needs are seen to be considered. In the case of the GBPA, all three of St. George's successors alienated a stakeholder group, resulting in reduced effectiveness of the SEZ management

In summary, while successive chairmen of the GBPA were all very astute businessmen in their own right, the passion and commitment to inspire residents, which include both the labour force and small business community appears to have been a missing link. In selection of future leaders for the GBPA, a greater focus should be placed on the value this human element has historically added to the overall growth of the city of Freeport.

\section{Conclusion}

The city of Freeport was originally planned and designed to be a vibrant and innovative model of the partnership between government and the private sector to achieve development. What began as a barren island devoid of infrastructure and development, eventually emerged as the jewel of industrialization in the Bahamian crown of islands. Previous work (Zeng, 2015; Long, 2018; Jones, 2019) all highlight the compelling need for strong leadership to ensure the success of SEZs. This area, however, has been little explored in the past.

This paper is a case study of the leadership style demonstrated by St. George while at the helm of the GBPA until his demise in 2004 based on anecdotal evidence and first-hand observations. The leadership skills demonstrated by St. George are best described as authentic leadership, transformational leadership and situational leadership, and are attributed to the growth and success of Freeport. The major stakeholder groups being impacted by this leadership have been defined as largely falling into the categories of foreign investor, government and domestic business/resident. Each leadership style was employed in turn at various stages based on the stakeholder group being interacted with at the time and for the betterment of Freeport.

This paper relies on anecdotal evidence, newspaper articles and other reports to create a picture of historic versus current leadership in Freeport. Incorporating analytical tools, such as a broad-based quantitative and qualitative survey of various stakeholder groups, may improve the understanding of the leadership challenges facing Freeport. Analysis of the type, scale and nature of businesses operating in Freeport in the past versus the current environment may also prove useful in examining the comparative and competitive advantages that may have also resulted in the current economic state of Freeport, beyond a change in leadership.

Nevertheless, shareholders of the GBPA are advised to pay greater attention to the authentic and transformational leadership skills demonstrated by its first chair, which created a sense of community and commitment by local residents. It is also crucial that all stakeholders' views are included, as part of a balanced approach to leadership. Providing greater focus on these aspects in a chair, along with a system of measuring and tracking performance based on the suggestions of Zeng (2015) may allow Freeport to rebound to its former glory days. 


\section{Acknowledgements}

An earlier draft of this paper benefited from feedback and guidance from Professor Chao Wang, National School of Development, Peking University, Beijing, China. Significant assistance in data and information gathering was provided by the staff of the Department of Statistics, Freeport Branch and the staff of the Northern Campus Library at the University of The Bahamas-North.

\section{References}

Amanchukwu, R. N., Stanley, G. J. \& Ololube, N. P. (2015). A review of leadership theories, principles and styles and their relevance to educational management. Management, 5(1), 6-14. https://doi.org/10.5923/j.mm.20150501. 02

Bahamas Department of Statistics. (2018, May). Preliminary results: Labour force survey report [Press release]. https://www.bahamas.gov.bs/wps/wcm/c onnect/a96946b4-48f2-40a4-862f8d40fa550d9a/PRESS+RELEASE++Pre liminary+Labour+Force+Survey+Result s+--+May+2018.pdf?MOD=AJPERES

Bass, B. M. \& Avolio, B. J. (1994). Improving organizational effectiveness through transformational leadership. Sage.

Bass, B. M. (1990). Bass \& Stogdill's handbook of leadership: Theory, research, and managerial application. Free Press.

Burns, J. M. (1978). Leadership. Harper \& Row.

Dames, C. (2006, July 24). Francis explains decision to leave port authority. The Bahama Journal. https://www.bahamasb2b.com/news/200 6/07/francis-explains-decision-to-leaveport-authority

Graen, G. B. (1976). Role-making processes within complex organizations. In M. D.
Dunnette (Ed.), Handbook of Industrial and Organizational Psychology (pp. 1202-1245). Rand McNally.

Graen, G. B., \& Cashman, J. (1975). A rolemaking model of leadership in formal organizations: A developmental approach. In J. G. Hunt \& L. L. Larson (Eds.), Leadership Frontiers (pp. 143166). Kent State University Press.

Graen, G. B., \& Uhl-Bien, M. (1995).

Relationship-based approach to leadership: Development of leadermember exchange (LMX) theory of leadership over 25 years: Applying a multi-level, multi-domain perspective. Leadership Quarterly, 6(2), 219-247. https://doi.org/10.1016/10489843(95)90036-5

Grand Bahama Port Authority Ltd. (2005). Rising to the Challenge. The Grand Bahama Port Authority Ltd.: 50th Anniversary Special Report. Caribbean Investment Profiles Ltd.

Greene, C. (1998, January). Community asked to give increased participation in schools: \$3.5M St. George's High School officially opened. The Freeport News, Weekender.

Hawksbill Creek, Grand Bahama (Deep Water Harbour and Industrial Area) (1955) Bahamas (Ch. 261). http://laws.bahamas.gov.bs/cms/images/ LEGISLATION/PRINCIPAL/1955/195 5 -

0005/HawksbillCreekGrandBahamaDee 
pWaterHarbourandIndustrialAreaAct_1. pdf

Hersey, P., \& Blanchard, K. H. (1969). Lifecycle theory of leadership. Training and Development Journal, 23, 26-34. https://psycnet.apa.org/record/197019661-001

Hersey, P., \& Blanchard, K. H. (1993). Management of organizational behavior: Utilizing human resources (6th ed.). Prentice Hall

Ian Fair departs GBPA. (2013, September 11). The Nassau Guardian. https://www.bahamaslocal.com/newsite m/81430/Ian_Fair_departs_GBPA.html

Jones, K. (2019). The impact of investment policy reform in FDI receipts in The Bahamas. [Unpublished master's thesis]. Peking University.

Jones, K. (2021). The impact of the 1992 investment policy reform on growth in The Bahamas. Social and Economic Studies, 69(1 \& 2), 107-132. https://www.mona.uwi.edu/ses/taxonom $\mathrm{y} /$ term $/ 538$

Katz, R. L. (1955). Skills of an effective administrator. Harvard Business Review, 33(1), 33-42.

https://hbr.org/1974/09/skills-of-aneffective-administrator

Khan, M. S., Khan, I., Qureshi, Q. A., Ismail, H. M., Rauf, H., Latif, A., \& Tahir, M. (2015). The styles of leadership: A critical review. Public Policy and Administration Research, 5(3), 87-92. https://www.iiste.org/ Journals/index.php/PPAR/article/viewFil e/20878/21131.

King, S. J. (2005). Julian Francis takes over: Former governor of the Central Bank assumes top role at the Grand Bahama Port Authority. In The Bahamas Handbook and Businessman's Manual
2006 (pp. 516-532). Etienne Dupuch Jr. Publications.

Kouzes, J., \& Posner, B. (1995). The leadership challenge. Jossey-Bass.

Long, G. (2018, October 18). FDI and China's economic development. Presentation to Peking University Institute of South-South Cooperation and Development.

Lussier, R., \& Achua, C. (2007). Leadership: Theory, application, \& skill development. Cenage.

The man who helped to rebuild Freeport: Edward St. George. (1981). In The Bahamas Handbook and Businessman's Annual 1981-82 (pp. 406-411). Etienne Dupuch Jr. Publications.

Mann, R. D. (1959). A review of the relationship between personality and performance in small groups. Psychological Bulletin, 56, 241-270. https://doi.org/10.1037/h0044587

McCartney, J. (2011, June 14). Cable: PM put GB economy in jeopardy. The Nassau Guardian. https://www.bahamaslocal.com/newsite m/24242/Cable_PM_put_GB_economy_ in_jeopardy.html

Nanjundeswaraswamy, T. S., \& Swamy, D. R. (2014). Leadership styles. Advances in Management, 7(2), 57-62. https://www.mnsu.edu/activities/leaders hip/leadership_styles.pdf

Northouse, P. (2016). Leadership: Theory and practice. Sage.

Percentie, L. (2005, January 11). St. George's generosity did not stop at social services. Freeport News. https://www.bahamasb2b.com/news/200 5/01/tribute-to-king-edward

Rost, J. (1991). Leadership for the twentyfirst century. Praeger. 
Rowe, W. G. (2007). Cases in leadership. Sage.

Stogdill, R. M. (1948). Personal factors associated with leadership: A survey of the literature. Journal of Psychology, 25, 35-71.

https://doi.org/10.1080/00223980.1948.9 917362

Val, C., \& Kemp, J. (2012). Leadership styles. Pathways: The Ontario Journal of Outdoor Education, 24(3), 28-31. https://files.eric.ed.gov/fulltext/EJ99401 2.pdf

Walumbwa, F. O., Avolio, B. J., Gardner, W. L., Wernsing, T. S., \& Peterson, S. J. (2008). Authentic leadership:

Development and validation of a theorybased measure. Journal of Management, 34(1), 89-126. https://doi.org/

\section{$10.1177 / 0149206307308913$}

World Bank. (2008). Special economic zones: Performance, lessons learned, and implications for zone development. https://tinyurl.com/worldbankSEZ2008

Zeng, D. Z. (2015, February). Global experiences with special economic zones: With a focus on China and Africa [Conference presentation]. Investing in Africa Forum, Addis Ababa, Ethiopia. https://openknowledge.worldbank.org/ha ndle/10986/21854

Zeng, D. Z. (2016). Special economic zones: Lessons from the global experience. PEDL Synthesis Paper Series No. 1. https://assets.publishing.service.gov.uk/ media/586f9727e5274a130700012d/PE DL_Synthesis_Paper_Piece_No_1.pdf 